\title{
ACE-2, TMPRSS2 and Beyond; Promising Targets and Tools for COVID-19 Prophylaxis and Treatment
}

\section{ACE-2, TMPRSS2 ve Ötesi; COVID-19 Profilaksisi ve Tedavisi için Umut Vaat Eden Hedefler ve Araçlar}

(i) Akçahan GEPDİREMEN1', iD Meltem KUMAŞ22

${ }^{1}$ Bezmialem Vakıf University Medical Faculty, Department of Medical Pharmacology, İstanbul, Turkey

${ }^{2}$ Dokuz Eylül University Faculty of Veterinary Medicine, Department of Histology and Embryology, İzmir, Turkey

\begin{abstract}
Several repurposing drugs and ongoing vaccine researches to combat Coronavirus Disease-19 (COVID-19) are testing clinically, worldwide. COVID-19 caused by severe acute respiratory failure syndrome-CoV-2, uses angiotensin-converting enzyme 2 (ACE2) as a functional receptor for entry into the cells, followed by its priming by transmembrane protease serine 2 (TMPRSS2). Most of the ACE-2 expressing cells are alveolar type II pneumocytes. Viral S-glycoprotein, TMPRSS2 and ACE-2 inhibition, as extracellular media components, are potential targets of future therapy. ACE2 and/or TMPRSS2 blockade is thought to be beneficial in the prevention or treating of this infection which will be the most convenient for pharmacoeconomics and effectiveness, regarding similar future pandemics. Despite substrate-based design and synthesis of ACE-2 inhibitor compounds were presented almost two decades ago, data on renin angiotensin system activation or its blockers, especially ACE-2, are limited by now. Priority must be given to design a convenient vaccine soon, but due to the high mutation ability of such viruses mean that new vaccines may need to be developed for each outbreak. So, de novo drugs such as ACE-2 or TMPRSS2 blockers need to be developed which can specifically block spike binding sites of the target cells and prevent virus intrusion, especially at the extracellular media, for future pandemics.
\end{abstract}

Keywords: ACE-2, COVID-19, SARS-CoV-2, RAAS, TMPRSS2, coronavirus

\section{ÖZ}

Başka endikasyonlar için ruhsatlandırılmış birçok ilaç ve aşı araştırmaları, Koronavirüs Hastalığı-19 (COVİD-19) ile savaşta tüm dünyada klinik olarak denenmektedir. COVİD-19'a yol açan ağır akut solunum yolu yetersizliği sendromu, transmembranal proteaz serin 2 (TMPRSS2) tarafından hazırlandıktan sonra, hücrelere giriş için fonksiyonel reseptör olarak anjiyotensin dönüştürücü enzim 2'yi (ACE-2) kullanır. En fazla ACE-2 eksprese edilen hücreler; alveoler tip 2 pnömositlerdir. Gelecekteki tedavilerin potansiyel hedefleri, ekstrasellüler ortam bileşenleri olarak; viral S-glikoprotein, TMPRSS2 ve ACE-2 enzimlerinin inhibisyonu olarak ön plana çıkmaktadır. İleride karşılaşılabilecek benzer pandemiler göz önüne alındığında, enfeksiyonların profilaksisi veya tedavisinde farmakoekonomik kriterler ve etkililik açısından en uygun olarak, ACE-2 ve/veya TMPRSS2 blokajının faydalı olabileceği düşünülmektedir. ACE2 inhibitörlerinin substrat bazlı tasarım ve sentezleri yaklaşık yirmi yıl önce tanımlanmış olmasına rağmen, renin anjiyotensin sistemi aktivasyonu veya inhibisyonunun ve özellikle de ACE-2 ile ilgili şimdiye kadar elde edilen veriler oldukça yetersizdir. Bu tip salgınlara ilişkin öncelik; uygun aşı tasarlanması ve geliştirilmesi olmakla beraber, bu ve benzer virüslerin yüksek mutasyon kapasiteleri sebebiyle, her salgın için yeni aşı geliştirilmesi gerekliliği aşikardır. Gelecekte ortaya çıkması muhtemel pandemiler için, virüsün hedef hücreye girişini sağlayan dikensi çıkıntıların (spike) bağlandığı ACE2 ve TMPRSS2 enzimlerini özgün şekilde bloke eden ve özellikle ekstrasellüler ortamda etki göstererek, virüsün hücre içerisine girişini önleyebilecek de novo ilaçların geliştirilmesi gereklidir.

Anahtar Sözcükler: ACE-2, COVID-19, SARS-CoV-2, RAAS, TMPRSS2, koronavirüs
Address for Correspondence: Akçahan GEPDIREMEN, Bezmialem Vakıf University Medical Faculty, Department of Medical Pharmacology, İstanbul, Turkey

E-mail: agepdiremen@bezmialem.edu.tr ORCID ID: orcid.org/0000-0002-5650-1280
Received: 04.06.2020

Accepted: 04.08.2020

Cite this article as: Gepdiremen A, Kumaş M. ACE-2, TMPRSS2 and Beyond; Promising Targets and Tools for COVID-19 Prophylaxis and Treatment. Bezmialem Science 2020;8(Supplement 3):79-83. 


\section{Introduction}

Coronavirus Disease-19 (COVID-19) pandemic caused by coronavirus SARS-CoV-2 uses the Angiotensin-converting enzyme 2 (ACE-2) as a functional receptor for entry into the cells and transmembrane protease serine 2 (TMPRSS2) for $S$ protein priming (1). The receptor binding domain of severe acute respiratory failure syndrome-CoV-2 (SARS-CoV-2) has a higher affinity for ACE-2, compared with SARS-CoV with the receptor binding domains of these two coronaviruses share $72 \%$ amino acid sequence identity (2). It was demonstrated that $83 \%$ of ACE- 2 expressing cells were alveolar epithelial type II and those types of cells serve as a reservoir for viral invasion (3). A minority of ACE-2 expressing cells are distributed in the intestine, endothelium, kidney, heart, etc. It is still a mystery that multi-organ invasion of SARS-CoV-2 infection unless viremia could be attributed to it, or not?

This study aims to provide a comprehensive view on COVID-19 and the future expectations to design effective therapeutics and control virus progression. Since effective prophylactics or therapeutics are not available, the development of vaccines and drugs for treatment and prevention of COVID-19 is the matter of emergency. Despite the priority given to the development of SARS-CoV-2 vaccine, new vaccines will need to be developed due to the high mutation rates of this virus (4). Yet, no SARS-CoV-2 therapeutics are currently available, albeit some treatment options which await validation. This could be counted as various antiviral drugs such as remdesivir/favipiravir, immunomodulatory drugs of interleukin-6 (IL-6) and IL-1 antagonists, thalidomide and pirfenidone which may suppress protective acute inflammatory responses, antimalarial drugs of chloroquine, hydroxychloroquine and mefloquine, $\mathrm{N}$-acetyl cysteine which is used to treat human immunodeficiency virus (HIV) and chronic obstructive pulmonary disease, sphingosine 1 phosphate receptor modulator which is approved for the treatment of multiple sclerosis, serine protease inhibitor of camostate mesylate, a low dose of corticosteroids and even some traditional compounds such as cepharanthine.

ACE and ACE-2, serve contrast physiological functions. ACE catalyzes angiotensin I to generate angiotensin II, which binds to and activates angiotensin II receptor type I (AT1R) and constricts blood vessels. ACE-2 inactivates angiotensin II while generating angiotensin 1-7, a heptapeptide having a potent vasodilator function via activation of its MAS receptors (5), as well as the production of nitric oxide and vasodilator prostaglandins (Figure 1). The S-glycoprotein on the surface of coronavirus binds to ACE-2. This leads to a conformational change in the S-glycoprotein and allows proteolytic digestion by host cell proteases (TMPRSS2) ultimately leading to internalization of the virion. Viral S-glycoprotein, TMPRSS2 and ACE-2 inhibition are potential targets of therapy and possible vaccine development (1).

As far as COVID-19 infection is concerned, the data on renin angiotensin system activation or its blockers on the present infection are limited at present. As ACE- 2 is the binding site for SARS-CoV-2, its blockade is thought to be beneficial in preventing or treating this infection (6). A retrospective analysis showed reduced rates of death and endotracheal intubation in patients with viral pneumonia who were continued on administration of ACE inhibitors (7). On the other hand, AT1R inhibitors [Angiotensin II Receptor Blockers (ARB's)] and angiotensin converting enzyme inhibitors (ACEi's) are warned of possibly harmful effect due to the increased viral entry into cells en since increased ACE-2 activity might increase viral entry into cells. Also, it was speculated that increased ACE-2 activity could induce conversion of angiotensin II to angiotensin-(1-7), a peptide with potentially protective anti-inflammatory properties (8). It is unclear whether an increasing anti-inflammatory activity is harmful or not in COVID-19 (9). Both ACEi and ARBs were reported to substantially increase ACE-2 activity in cardiac myocytes over one to two weeks in Lewis Rats (10). Olmesartan, an AT1R blocker, when chronically intake for more than one year, found to increase urinary ACE-2 level, which could potentially offer additional renoprotective effects in human (11). Other AT1R antagonist of losartan and olmesartan were shown to increase cardiac ACE-2 expression about three-fold following chronic treatment (28 days) after myocardial infarction induced by coronary artery ligation of rats (12). Conversely, mice with coronavirus induced lung injury showed improvement when treated with an angiotensin receptor blocker, losartan (13). In another study, losartan was shown to upregulate renal ACE-2 expression in chronically treated rats, for more than one year (14). According to the data, mostly obtained from animal models as well as a limited number of human retrospective studies speculate that the treatment with ACE inhibitors and ARB's could cause upregulation of ACE-2 (15). Moreover, Ibuprofen (A non steroidal anti inflammatory drug) and thiazolidinediones (an oral antidiabetic drug group) have also been claimed to do the same (16). Increased expression of ACE-2 speculated to increase the risk of infection with SARS CoV-2, caused serious hesitations in people with hypertension or diabetes who are at already elevated risk of infections. However, there is not enough evidence to support this yet. According to timelines of a basic biological process which were compared in human versus rats and they were found as; 2.5-84 fold faster in rats. Moreover, in the aged phase, one human year was reported to equal 17.1 rat days (17). Thus, it may speculate the upregulation of tissue ACE-2 levels due to the intake of ACEi or ARB's requisite to take a much longer period for human, in respect to laboratory animals. On the other hand, if those drugs cause such fold ACE2 expression following chronic treatment, it was expected to the increased conversion of angiotensin II to angiotensin-(1-7), stronger vasodilatation and some other protective effects due to the extensive MAS receptors stimulation, but not. Conversely, the doses of ACE inhibitors or ARB's need to be increased in years to reach the same clinical response, in hypertension patients. Moreover, in a retrospective analysis of 112 COVID-19 hospitalized patients with cardiovascular disease in WuhanChina, no significant difference was found in the proportion of ACEi/ARB medication between non-survivors and survivors (18). So, ACEi/ARB use probably does not affect the morbidity 
and mortality of COVID-19 combined with cardiovascular diseases, though more comprehensive retrospective data are needed. Experimental results obtained from laboratory animals cannot be regarded as a criterion for human.

Beyond the testing repurposing drugs on COVID-19 prophylaxis and treatment which are listed above, spike-protein based vaccines, TMPRSS2 inhibition by the administration of the compounds such as nafamostat mesylate and bromhexine hydrochloride, delivering the soluble form of recombinant human ACE-2 which could competitively bind and neutralize the virus, as well as may rescue membranal ACE-2 enzyme, should carry on priority (Figure 2). For SARS-CoV, $\mathrm{IC}_{50}$ value for camostate mesylate was found as; $0.68 \mathrm{nM}$, while for SARS-CoV-2, bromhexine's $\mathrm{IC}_{50}$ value was determined as; $0.75 \mu \mathrm{M}$ and in pulmonary and bronchial epithelial cells, it may reach concentrations of 4 to 6 -fold higher than those found in the plasma (19). Also, gabexate and nafamostat mesylate were studied and the latter one reported to inhibit SARS-CoV-2 S-mediated entry into host cells with roughly 15-fold-higher efficiency than camostat mesylate, with an $\mathrm{EC}_{50}$ in the low nanomolar range (20). Also, a new generation of TMPRSS2 inhibitor molecules was presented recently with their docking scores (21).

Furin, which is mainly located in lysosomes, is activated by endo-lysosomal acidification and is also taking action in the pathogenesis of some viral infections such as HIV and other coronaviruses, where it cleaves viral enveloping proteins and permeating viral functionality (22). It exerts its action in intracellular, as well as extracellular compartments, which means it exists also as a circulating enzyme (23). Furin inhibitors were reported to block extracellular anchoring activity (cleavage site at the junction between the S1/S2 subunits), but not intracellular processes of viruses (24), which proves the primary tools to combat with SARS-CoV-2 has to be mainly at the extracellular matrix. That's why blockade of another important endo-lysosomal enzyme of cathepsine-L by potent and selective molecules such as; SID 26681509 seems not as important as the other molecules mentioned in that text, as first line drug development priorities (Figure 1).
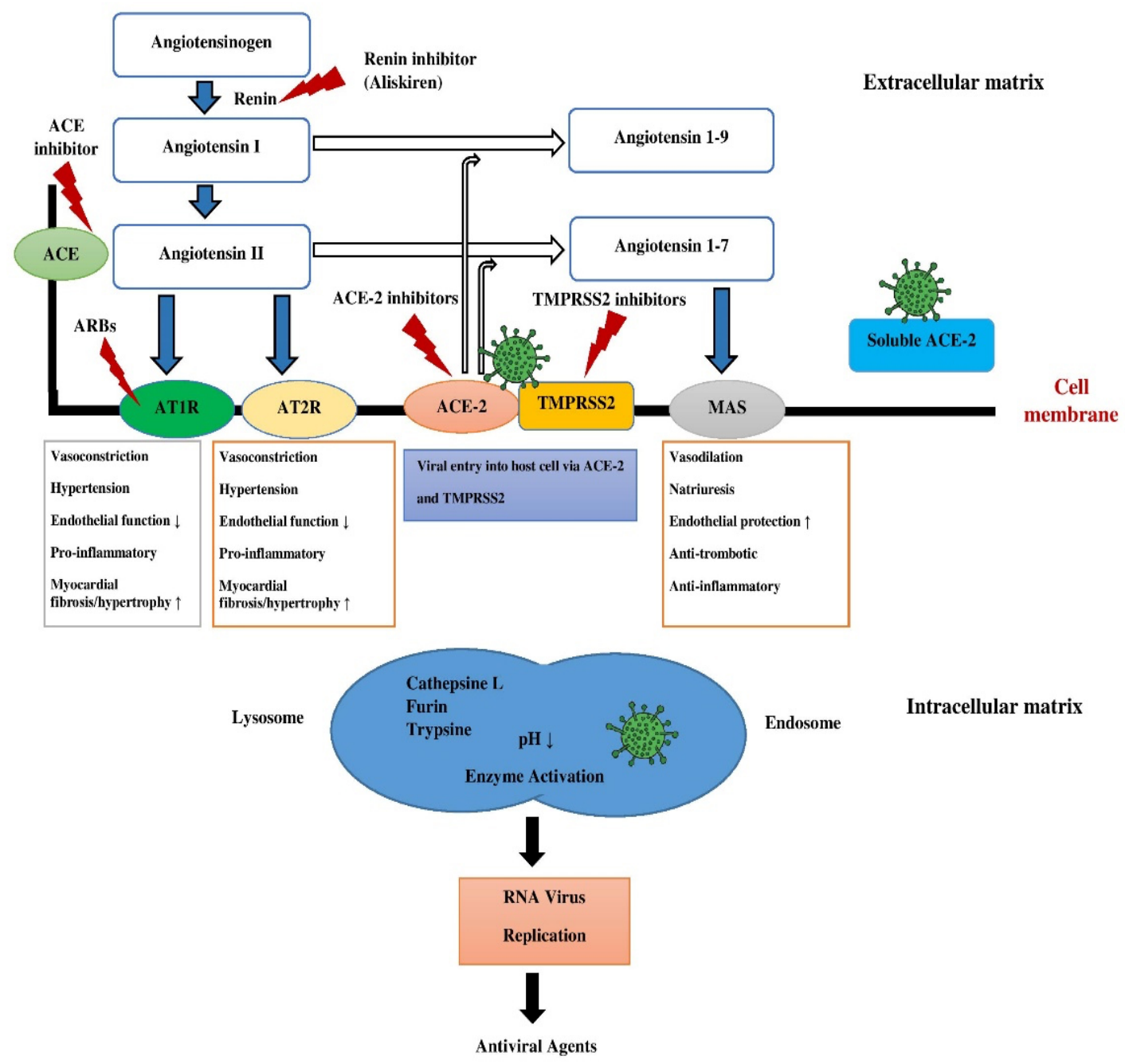

Figure 1. Renin angiotensin system physiology, pharmacology, and the binding domain of COVID-19

ACE: Angiotensin converting enzyme; ACE-2: Angiotensin converting enzyme 2, TMPRSS2: Transmembrane protease serine 2, ARBs: Angiotensin II receptor blockers, AT1R: Angiotensin type 1 receptor, AT2R: Angiotensin type 2 receptor, MASR: Angiotensin (1-7) receptor 
Another promising group for de novo drug development is ACE2 enzyme inhibitors, which could be very convenient for costeffectiveness and potency, regarding similar future outbreaks. Substrate based design and synthesis of ACE-2 inhibitor

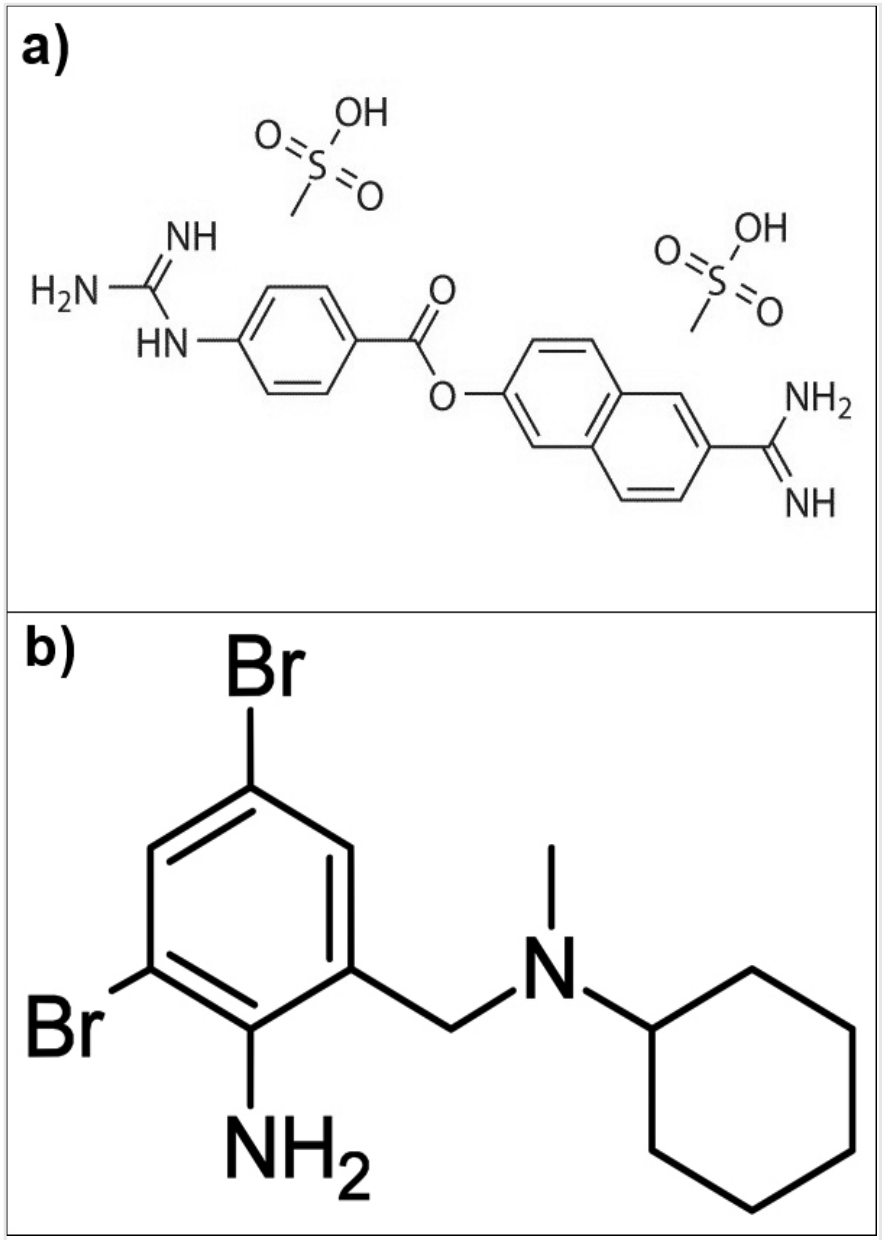

Figure 2. Chemical structure of some transmembrane protease serine 2 (TMPRSS2) inhibitors (a: Nafamostat mesylate, b: Bromhexine hydrochloride) compounds were firstly introduced in 2002 and that catalytic activity of ACE- 2 was found to be not able to suppress by ACE inhibitors because of ACE is a peptidyl dipeptidase while ACE-2 is a carboxypeptidase (25). A few years ago, a new generation of ACE2 inhibitors such as MLN-4760, VE-607, N-2195, DX-600, G-3050, etc. was presented, as still in ongoing preclinical trials (26) (Figure 3). During the acute respiratory distress syndrome, not only ACE/ACE-2 ratio was found to be reduced, but also it could be reported to prevent by angiotensin-(1-7) or angiotensin receptor blockers (27). SARS virus spike protein binding site is located in a different region (suggesting that sequences between amino acids 766 and 771 are required for the insertion of ACE2 into the plasma membrane) from which is required for the enzymatic function of ACE-2 (28). The successful prevention of the virus cleavage by the new generation of ACE-2 inhibitors is still a matter of doubt. However, due to the importance of ACE-2 in COVID-19, beyond the synthesis of soluble ACE2 , the development of inhibitors mimicking the S-interaction domain in ACE-2 could be employed as a first line therapy for future pandemics. Another major attack of coronavirus which is expected within the next decade, could be more severe than the current one. Therefore, effective therapeutics should be developed based on the already obtained clinical and research information about SARS-CoV-2. The aim of this review was to summarize the possible future preventive and treatment options of coronavirus acquired during this SARS-CoV-2 outbreak.

Peer-review: Externally peer reviewed.

\section{Authorship Contributions}

Concept: A.G., Design: M.K., Data Collection or Processing: A.G., M.K., Analysis or Interpretation: A.G., Literature Search: A.G., M.K., Writing: A.G., M.K.

Conflict of Interest: No conflict of interest was declared by the authors.

Financial Disclosure: The authors declared that this study received no financial support.

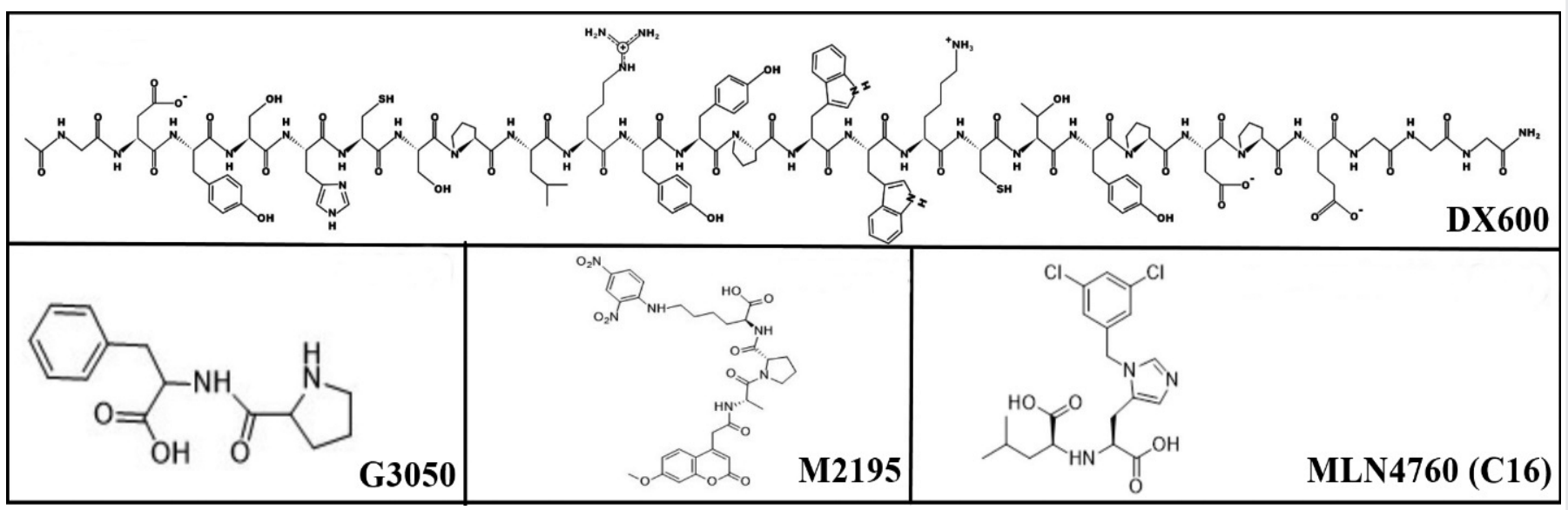

Figure 3. Chemical structure of some angiotensin converting enzyme 2 (ACE-2) inhibitors 


\section{References}

1. Hoffmann M, Kleine-Weber H, Schroeder S, Krüger N, Herrler T, Erichsen S, et al. SARS-CoV-2 Cell entry depends on ACE2 and TMPRSS2 and is blocked by a clinically proven protease inhibitor. Cell 2020;S0092-8674:30229-34.

2. Chen Y, Guo Y, Pan Y, Zhao ZJ. Structure analysis of the receptor binding of 2019-nCOV. Biochemical and Biophysical Research Communication. 2020;525:135-40.

3. Zhao Y, Zhao Z, Wang Y, Zhou Y, Ma Y, Zuo W. Single-cell RNA expression profiling ofACE2, the putative receptor of Wuhan Covid-19. BioRxiv 2020; https://doi.org/10.1101/2020.01.26.919985. [Epub ahead of print].

4. Belongia EA, Skowronski DM, McLean HQ, Chambers C, Sundaram $\mathrm{ME}, \mathrm{De}$ Serres G. Repeated annual influenza vaccination and vaccine effectiveness: review of evidence. Expert Rev Vaccines 2017;16:1-14.

5. Santos RA, Silva ACS, Maric C, Silva DM, Machado RP, de Buhr I, et al. Angiotensin-(1-7) is an endogenous ligand for the $G$ proteincoupled receptor Mas. Proc Nati Acad Sci 2003;100:8258-63.

6. Gupta R, Misra A. Contentious issues and evolving concepts in the clinical presentation and management of patients with COVID-19 infectionwith reference to use of therapeutic and other drugs used in Co-morbid diseases (Hypertension, diabetes etc). Diabetes Metab Syndr 2020;14:251-4.

7. Henry C, Zaizafoun M, Stock E, Ghamande S, Arroliga AC, White HD. Impact of angiotensin-converting enzyme inhibitors and statins on viral pneumonia. Baylor University. Medical Center Proceedings 2018;21:419-23.

8. Namsolleck P, Recarti C, Foulquier S, Steckelings UM, Unger T. AT(2) receptor and tissue injury: therapeutic implications. Curr Hypertens Rep 2014;16:416.

9. Aronson JK, Ferner RE. Drugs and the renin-angiotensin system in covid-19. BMJ 2020;369:m1313

10. Ferrario CM, Jessup J, Chappell MC, Averill DB, Brosnihan KB, Tallant EA, et al. Effect of angiotensin-converting enzyme inhibition and angiotensin II receptor blockers on cardiac angiotensinconverting enzyme 2. Circulation 2005;111:2605-10.

11. Furuhashi M, Moniwa N, Mita T, Fuseya T, Ishimura S, Ohno K, et al. Urinary angiotensin-converting enzyme 2 in hypertensive patients may be increased by olmesartan, an angiotensin II receptor blocker. Am J Hypertens 2015;28:15-21.

12. Ishiyama Y, Gallagher PE, Averill DB, Tallant EA, Brosnihan KB, Ferrario CM. Upregulation of angiotensin-converting enzyme 2 after myocardial infarction by blockade of angiotensin II receptors. Hypertension 2004;43:970-6.

13. Yang P, Gu H, Zhao Z, Wang W, Cao B, Lai C, et al. Angiotensinconverting enzyme 2 (ACE2) mediates influenza H7N9 virusinduced acute lung injury. Sci Rep 2014;13:7027.

14. Klimas J, Olvedy M, Ochodnicka-Mackovicova K, Kruzliak P, Cacanyiova S, Kristek F, et al. Perinatally administered losartan augments renal ACE2 expression but not cardiac or renal Mas receptor in spontaneously hypertensive rats. J Cell Mol Med 2015;19:196574.
15. Li XC, Zhang J, Zhuo JL. The vasoprotective axes of the reninangiotensin system: Physiological relevance and therapeutic implications in cardiovascular, hypertensive and kidney diseases. Pharmacol Res 2017;125:21-38.

16. Fang L, Karakiulakis G, Roth M. Are patients with hypertension and diabetes mellitus at increased risk for COVID-19 infection? Lancet Respir Med 2020;8:e21.

17. Sengupta P. The Laboratory Rat: Relating Its Age With Human's. Int J Prev Med 2013;4:624-30.

18. Peng YD, Meng K, Guan HQ, Leng L, Zhu RR, Wang BY, et al. Clinical characteristics and outcomes of 112 cardiovascular disease patients infected by 2019-nCoV. Zhonghua Xin Xue Guan Bing Za Zhi. 2020;48:E004.

19. Maggio R. Repurposing the mucolytic cough suppressant and TMPRSS2 protease inhibitor bromhexine for the prevention and management of SARS-CoV-2 infection. Pharmacol Res 2020;157:104837.

20. Hoffmann M, Schroeder S, Kleine-Weber H, Müller MA, Drosten C, Pöhlmann S. Nafamostat Mesylate Blocks Activation of SARSCoV-2: New Treatment Option for COVID-19. Antimicrob Agents Chemother 2020;64:e00754-20.

21. Rahman N, Basharat Z, Yousuf M, Castaldo G, Rastrelli L, Khan H. Virtual Screening of Natural Products against Type II Transmembrane Serine Protease (TMPRSS2), the Priming Agent of Coronavirus 2 (SARS-CoV-2). Molecules 2020;25:E2271.

22. Hallenberger S, Bosch V, Angliker H, Shaw E, Klenk HD, Garten W. Inhibition of furin-mediated cleavage activation of HIV-1 glycoprotein gp160. Nature 1992;360:358-61.

23. Ichiki T, Burnett JC Jr. Post-transcriptional modification of proBNP in heart failure: is glycosylation and circulating furin key for cardiovascular homeostasis? Eur Heart J 2014;35:3001-3.

24. Van Lam van T, Ivanova T, Hardes K, Heindl MR, Morty RE, BöttcherFriebertshäuser E, et al. Design, synthesis, and characterization of macrocyclic inhibitors of the proprotein convertase furin. Chem Med Chem 2019;14:673-85.

25. Dales NA, Gould AE, Brown JA, Calderwood EF, Guan B, Minor $\mathrm{CA}$, et al. Substrate-based design of the first class of angiotensinconverting enzyme-related carboxypeptidase (ACE2) inhibitors. J Am Chem Soc 2002;124:11852-3.

26. Tamargo M, Tamargo J. Future drug discovery in renin-angiotensinaldosterone system intervention. Expert Opin Drug Discov 2017;12:827-48.

27. Wösten-van Asperen RM, Lutter R, Specht PA, Moll GN, van Woensel $\mathrm{JB}$, van der Loos CM, et al. Acute respiratory distress syndrome leads to reduced ratio of ACE/ACE2 activities and is prevented by angiotensin-(1-7) or an angiotensin II receptor antagonist. J Pathol 2011;225:618-27.

28. Hofmann H, Geier M, Marzi A, Krumbiegel M, Peipp M, Fey GH, et al. Susceptibility to SARS coronavirus $S$ protein-driven infection correlates with expression of angiotensin converting enzyme 2 and infection can be blocked by soluble receptor. Biochem Biophy Res Commun 2004;319:1216-21. 